\title{
HYDROTHERMAL TREATMENT FAVORS PEELING OF 'PERA'SWEET ORANGE FRUIT AND DOES NOT ALTER QUALITY
}

\author{
Maria Cecília de Arruda ${ }^{1 *}$; Angelo Pedro Jacomino ${ }^{2} ;$ Ana Luíza Pinheiro²; Rafael Vasconcelos \\ Ribeiro $^{3}$; Michelle Antonio Lochoski²; Raquel Capistrano Moreira ${ }^{4}$ \\ ${ }^{1}$ APTA/Pólo Regional de Desenvolvimento Tecnológico dos Agronegócios do Centro Oeste Paulista, Av. Rodrigues \\ Alves, 40-40 - 17030-000 - Bauru, SP - Brasil. \\ ${ }^{2}$ USP/ESALQ - Depto. de Produção Vegetal, C.P. 09 - 13418-900 - Piracicaba, SP - Brasil. \\ ${ }^{3}$ IAC/Centro de Pesquisa e Desenvolvimento de Ecofisiologia e Biofísica - Setor de Fisiologia Vegetal, C.P. 28 - \\ 13001-970 - Campinas, SP - Brasil. \\ ${ }^{4}$ Centro de Pesquisas e Desenvolvimento Leopoldo Américo Miguez de Mello - CENPES, Av. Horácio Macedo, \\ 950 - 21941-598 - Rio de Janeiro, RJ - Brasil. \\ *Corresponding author 〈mcarruda@aptaregional.sp.gov.br>
}

ABSTRACT: Consumer demand for ready-to-eat-products has stimulated the development of new processing techniques to prepare fresh-cut fruit and vegetables. The aim of this study was to propose a peeling method for 'Pera' oranges (Citrus sinensis [L.] Osb.) by using a hydrothermal treatment and to determine its influence on the respiratory activity, physicochemical and sensorial characteristics, as well as on the peeling time. Cooled oranges $\left(6^{\circ} \mathrm{C}\right)$ were immersed in heated water $\left(50^{\circ} \mathrm{C}\right)$ for eight minutes and then, peeled and stored at $6^{\circ} \mathrm{C}$. The internal fruit temperatures taken at 1 and $3 \mathrm{~cm}$ depths (from fruit surface) were $15^{\circ} \mathrm{C}$ and $10^{\circ} \mathrm{C}$, respectively, at the end of the hydrothermal treatment. Non-hydrothermallytreated peeled oranges were used as control. The peeling time for treated oranges was 3.2 times as short as the time used for the control. The yield of marketable oranges was $95 \%$ for hydrothermally-treated oranges versus $60 \%$ for control. The respiratory activity of hydrothermally-treated oranges was greater than that of control oranges only during the first hour after peeling. The hydrothermal treatment influenced neither the physicochemical quality (given by soluble solids, titratable acidity and ascorbic acid content) nor fruit flavor. Oranges peeled with the aid of the hydrothermal treatment had better appearance. The hydrothermal treatment makes the peeling of oranges easier and does not affect their respiratory activity or their physicochemical and sensorial qualities.

Key words: Citrus sinensis, fresh-cut, temperature

\section{TRATAMENTO HIDROTÉRMICOFACILITA O DESCASCAMENTO DE LARANJA 'PERA'E NÃO AFETASUA QUALIDADE}

RESUMO: A demanda dos consumidores por produtos 'prontos para o consumo' tem estimulado o desenvolvimento de técnicas de processamento para preparar frutas e hortaliças minimamente processadas. O objetivo deste trabalho foi propor um método de descascamento para laranja 'Pera' (Citrus sinensis [L.] Osb.) pelo uso do tratamento hidrotérmico e determinar sua influência na atividade respiratória, características físico-químicas e sensoriais e no tempo de descascamento de laranja 'Pera'. Frutos resfriados $\left(6^{\circ} \mathrm{C}\right)$ foram imersos em água aquecida $\left(50^{\circ} \mathrm{C}\right)$ por oito minutos e em seguida descascados e armazenados a $6^{\circ} \mathrm{C}$. A temperatura interna do fruto medida na profundidade de 1 e $3 \mathrm{~cm}$ foi de $15^{\circ}$ e $10^{\circ} \mathrm{C}$ respectivamente, ao final do tratamento hidrotérmico. Laranjas descascadas sem tratamento hidrotérmico foram utilizadas como controle. O tempo de descascamento das laranjas submetidas ao tratamento hidrotérmico foi 3,2 vezes menor em relação às laranjas controle. $\mathrm{O}$ rendimento em laranjas comercializáveis foi de $95 \%$ para laranjas tratadas hidrotermicamente contra $60 \%$ para laranjas controle. A atividade respiratória das laranjas tratadas hidrotermicamente foi maior que das laranjas controle apenas na primeira hora após o descascamento. O tratamento hidrotérmico não influenciou a qualidade físico-química (sólidos solúveis, acidez titulável e ácido ascórbico) e nem o sabor das laranjas. As laranjas descascadas com auxílio do tratamento hidrotérmico foram preferidas quanto à aparência. $\mathrm{O}$ tratamento hidrotérmico facilita o descascamento de laranja 'Pera' e não afeta a atividade respiratória nem sua qualidade sensorial e físico-química.

Palavras-chave: Citrus sinensis, processamento mínimo, temperatura 


\section{INTRODUCTION}

Brazil is worldwide the largest citrus producer, where the most important fruits are oranges (Citrus sinensis [L.] Osb.), tangerines (Citrus reticulate Blanco, Citrus deliciosa Tenore) and acid limes (Citrus latifolia Tanaka) (FNP, 2006). Around 2 million tons of oranges are directed to the in natura fruit market of Brazil every year (FNP, 2006). Most of this fruit is retailed in bags containing from 1 to $5 \mathrm{~kg}$ and consumed as juice in homes and restaurants, since oranges are little convenient for consumption in natura. In this case, oranges have to be peeled and, sometimes, sliced. On the other hand, the preparation of oranges to be offered to restaurant customers is expensive.

An alternative to increase the consumption of oranges in natura and not as juice, is the minimal processing which enables the use of oranges in natura conveniently. The total peeling of oranges, that is, the removal of flavedo and albedo, carried out manually and without fruit treatment, is made difficult due to the adherence of the albedo to the segment membrane. Treatments aimed at making peeling easier have been looked for.

A process for citrus peeling was developed and patented by Bruemmer (1981). This method consists of scoring or perforating the fruit peel, submerging the fruit into solution containing enzyme, and forcing the solution into the peel by vacuum. In such process, the enzyme dissolves the pectin and cellulose of the albedo and segment membrane region, making peeling and segmentation easier. However, enzymatic-peeled citric fruits show excessive juice leakage and softening (Pao et al., 1996). So, Pao et al. (1996) demonstrated that water alone can be infused by vacuum or pressure in fruits scored to facilitate peeling, and thus the result is a firm product with less juice leakage.

The aim of this work was to propose a peeling method for 'Pera' oranges by using a hydrothermal treatment and to determine its influence on the respiratory rate, physicochemical and sensorial characteristics, as well as on the peeling time.

\section{MATERIAL AND METHODS}

'Pera' sweet oranges were harvested in a commercial orchard in Engenheiro Coelho, Sao Paulo, Bra-

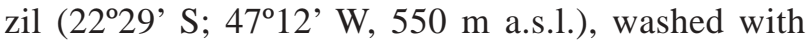
neutral detergent, sanitized with chlorinated water (200 $\mathrm{mg}$ of active chlorine $\mathrm{L}^{-1}$ ), cooled at $6^{\circ} \mathrm{C}$ for 12 hours and processed. Fruit weighed about $200 \mathrm{~g}$ and presented a greenish-yellow skin, $4.5 \pm 0.5 \mathrm{~mm}$ thick.

The hydrothermal treatment consisted of putting fruit in heated water at around $50^{\circ} \mathrm{C}$ for eight min- utes. This exposure time and temperature were determined in previous tests, in which temperature varied between 40 and $60^{\circ} \mathrm{C}$ and exposure time from three to eight minutes (data not shown). Then, the combination (temperature/time) that turned the peeling of oranges easier and that did not leave excessive albedo was chosen. Fruit were peeled first opening a gap in the peduncular region with a knife and the flavedo and albedo were manually removed. Peeling of nonhydrothermically treated fruit was conducted by first removing the flavedo with a knife and, then, removing the albedo from a gap in the fruit peduncular region.

\section{Internal fruit temperature}

The internal temperature of oranges was evaluated at 1 and $3 \mathrm{~cm}$ depth in relation to the epicarp, inserting type-T thermocouples (copper-constantan) in the equatorial region of cooled fruits $\left(6^{\circ} \mathrm{C}\right)$. Then, oranges were immersed in a water bath (hydrothermal treatment) at $50^{\circ} \mathrm{C}$. The temperature data were recorded every second for 20 minutes using a CR23X Micrologger (Campbell Scientific, Inc., Logan USA). Seven replications were used for each fruit. The water temperature was also monitored during hydrothermal treatment by using a thermocouple.

\section{Peeling time}

For measuring the peeling time, four people peeled 80 oranges, with each person peeling ten hydrothermally-treated oranges and ten non-treated ones (control). Each person peeled the oranges from each treatment alternately. The average time for pealing each orange and the yield of marketable product were evaluated. Oranges showing injuries of $1 \mathrm{~cm}^{2}$ or more, or showing more than three injuries smaller than 1 $\mathrm{cm}^{2}$ were considered unsuitable for commercialization.

\section{Physicochemical analyses}

Physicochemical and sensorial analyses were carried out together. For the preparation of samples to be tasted, a piece of each orange was spared for the following analyses: a) soluble solids ( ${ }^{\circ}$ Brix): direct reading in an Atago digital refractometer Palete 101 model, using homogenized juice from the plot; b) titratable acidity (\%): by titration with $\mathrm{NaOH}$, according to the methodology described by Carvalho et al. (1990), using homogenized juice from the plot; c) ascorbic acid: by titration with DCPIP $(2,6-$ dichlorophenolindophenol sodium), according to the methodology described by Carvalho et al. (1990), using homogenized juice from the plot. The ratio between soluble solids and titratable acidity was calculated. 


\section{Appearance and flavor}

A paired preference test to assess the choice of a sample over another was used in order to judge the appearance of fruits (Ferreira et al., 2000). This test was carried out on the second day after fruit processing and involved 48 untrained judges. An acceptability test was also conducted by a team of 48 untrained judges to assess the appearance of fruits according to the following score: 5-excellent, 4-good, 3fair, 2-bad and 1-very bad.

Flavor was evaluated on the $1^{\text {st }}$ and $4^{\text {th }}$ days of storage through a triangular test to determine whether there was a noticeable difference between two products by comparing three samples, two of them the same and one different. Then, 36 untrained judges were asked to identify the different sample in each group of three samples (Ferreira et al., 2000). The recruiting of judges was based on their attitude regarding the product (like or dislike it). Samples of approximately $25 \mathrm{~g}$ were offered to the judges in a randomized and balanced order, according to the following design: $\mathrm{ABA}, \mathrm{BAB}, \mathrm{AAB}, \mathrm{BBA}, \mathrm{ABB}$ and $\mathrm{BAA}$, where $A$ was the hydrothermally treated orange and $B$ the control one.

\section{Respiratory activity}

The respiratory activity was determined for fruit submitted to hydrothermal treatment and control. Peeled fruit were placed into sealed containers and stored in a B.O.D. chamber at $6^{\circ} \mathrm{C}$ for 4 days. The containers were kept closed for 30 minutes before sample collection and kept open after this. Measurements were carried out immediately after processing and hourly after it, for a period of ten hours. After that, measurements were conducted every 24 hours during the storage period (four days). Gas samples were taken from each container through a silicon septum and injected into a gas chromatographer Trace 2000 GC (Thermoffinigan, Rodano Milan, Italy) equipped with a Porapack N column, a methanator and a flame ionization detector (FID). Calibration standards for assessing carbon dioxide $\left(\mathrm{CO}_{2}\right)$ were 2150 and $2900 \mu \mathrm{L} \mathrm{CO}_{2} \mathrm{~L}^{-1}$. Results, in $\mu \mathrm{L} \mathrm{CO} \mathrm{L}^{-1}$, were used to calculate the respiratory activity $\left(\mathrm{mL} \mathrm{CO}_{2} \mathrm{~kg}^{-1} \mathrm{~h}^{-1}\right)$, considering the container volume, mass of fruit and the period of time the containers remained closed.

\section{Statistical analysis}

The data were submitted to ANOVA and, when statistical significance was detected, means were compared by the Tukey test $(P<0.05)$. The number of replications, representing one to ten oranges each, varied from four to six. Sensorial analysis for taste (triangular test) and external appearance (paired preference and structured scale) were carried out in accordance with the values in Table 1 .

\section{RESULTS AND DISCUSSION}

\section{Internal fruit temperature}

Pulp temperatures measured at 1 and $3 \mathrm{~cm}$ depths gradually increased until reaching around $30^{\circ} \mathrm{C}$ and $25^{\circ} \mathrm{C}$, respectively, after 20 minutes of treatment (Figure 1). However, the hydrothermal treatment for peeling oranges takes eight minutes, which is enough

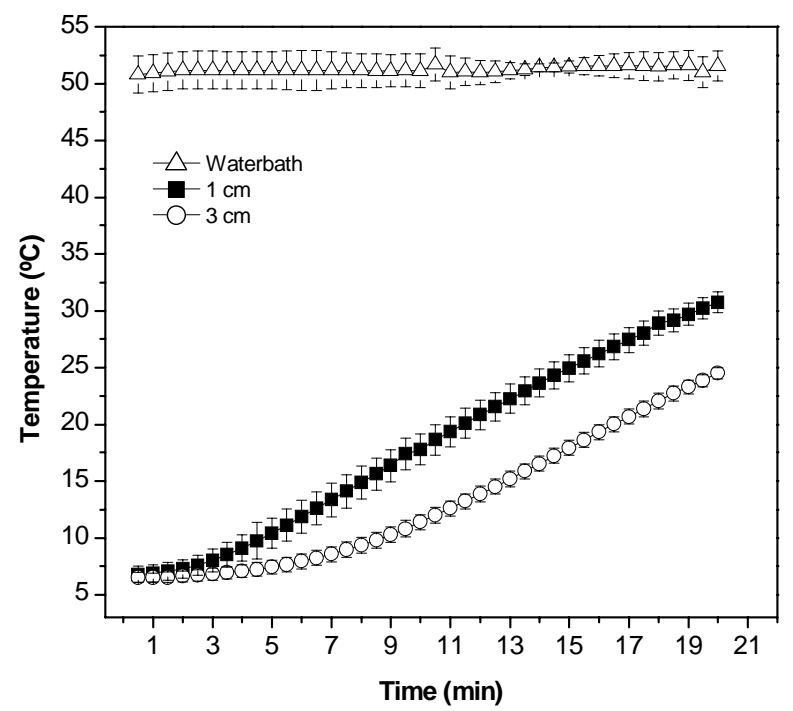

Figure 1 - Time-course of fruit and water bath temperatures during the hydrothermal treatment. Internal fruit temperatures at 1 and $3 \mathrm{~cm}$ depth are shown. Each point represents the mean value of seven replications $( \pm \mathrm{SD})$.

Table 1 - Minimum numbers of correct judgments to establish significance at various probability levels for the triangle test and minimum numbers of judgments in favor of a certain sample to establish significance at various probability levels for paired-preference test.

\begin{tabular}{llccc}
\hline \multirow{2}{*}{ Number of judges } & \multicolumn{3}{c}{ Test } & \multicolumn{3}{c}{ Probability level } \\
\cline { 3 - 4 } & & 5 & 1 & 0.1 \\
\hline 36 & Triangular test (taste) & 18 & 20 & 22 \\
48 & Paired preference (appearance) & 32 & 34 & 36 \\
\hline
\end{tabular}

Source: Meilgaard et al.(1991); O’Mahony (1986). 
to make peeling easier, without excessive fruit heating. Temperatures at 1 and $3 \mathrm{~cm}$ depths after eight minutes were approximately $15^{\circ} \mathrm{C}$ and $10^{\circ} \mathrm{C}$, respectively. The high juice amount, the low initial fruit temperature $\left(6^{\circ} \mathrm{C}\right)$, and the thermal insulation promoted by the orange skin, unlike fruits with thinner skin, such as papaya and mango, contributed to the little increase of internal temperature. In fact, mango and papaya showed higher heating rates than oranges when immersed in water at $48^{\circ} \mathrm{C}$, which is related with the lower density of oranges (Shellie \& Mangan, 2000).

\section{Peeling time}

Treated oranges showed peeling time 3.2 times as short as control. The average peeling time for treated oranges was $1 \mathrm{~min}$ and $14 \mathrm{sec}$ per fruit, while the peeling time for control oranges was $4 \mathrm{~min}$ and 1 sec. Besides reducing the peeling time, the hydrothermal treatment allowed a greater number of intact oranges. They yield of marketable oranges was $95 \%$ for hydrothermically treated oranges, as compared with $60 \%$ for non-treated oranges. However, excessively unripe oranges or oranges presenting excessively thick skin were difficult to be peeled within the treatment time, leading to many fruit injuries. This must be considered in commercial scale production. Heating times longer than eight minutes may be necessary for oranges presenting thicker skin. An adapted automated system to control the flow of fruits and the hydrothermal treatment times is necessary when considering their implementation in commercial scale.

Peeling time for 'Hamlin' orange infused with water under vacuum or pressure was around $20 \pm 3$ seconds (Pao et al., 1998). Although the peeling time by the hydrothermal technique is higher, this technique offers as an advantage of no need for perforating fruit peel and using vacuum or pressure. Moreover, the oranges undergoing hydrothermal treatment did not exhibit juice leakage. Manual peeling of non-treated oranges is more difficult, as the albedo becomes firmly attached to membrane segments, which leads to more injured fruits, unsuitable for commercialization. Pao et al. (1996) studied the effect of infusion in water and enzymatic solution associated to incisions in fruit skin, pressure and vacuum. The authors suggested that the water dissolves the albedo pectin making peeling easier.

\section{Physicochemical analyses}

Soluble solids (SS), titratable acidity (TA) and ascorbic acid content were not influenced by hydrothermal treatment, time or the interaction among them (Table 2).

Minimally processed 'Shamouti' oranges stored at $4^{\circ} \mathrm{C}$ for 12 days did not show changes in soluble solids amount, titratable acidity and ascorbic acid during the storage period (Del Caro et al., 2004). Minimally processed 'Pera' oranges also presented stability of physicochemical characteristics during storage (Donadon, 2005). The flavor of citrus fruits is a function of relative levels of soluble solids and titratable acidity, and presence or absence of various aromatic or bitter principles. In many citrus-growing regions of the world, citrus fruits are deemed to be marketable when a minimum SS:TA ratio is attained. This minimum ratio varies with location and local standards but generally ranges from seven to nine for oranges (Davies \& Albrigo, 1994). According to orange classification, standardization and identification norms of the Brazilian Program for Improvement of Commercial Standards and Packaging of Farm Products, the minimum ratio is 9.5 (HORTIBRASIL, 2006). In the present study, the ratio varied from 11.4 to 13.3. Studying hydrothermally treated bananas (48 to $50 \%$ 5-15 $\mathrm{min}$ ) to promote insect disinfestation, Wall (2004) did not observe any influence of the hydrothermal treatment on the soluble solids amount or on the titratable acidity.

\section{Appearance and flavor}

According to the sensorial analysis, the number of correct answers indicating that hydrothermallytreated oranges had different flavor in relation to control ones was 10 and 12 on the $1^{\text {st }}$ and $4^{\text {th }}$ days, respectively. According to the O'Mahony (1986) test,

Table 2 - Physicochemical characteristics of control and hydrothermally treated 'Pera' sweet orange.

\begin{tabular}{|c|c|c|c|c|}
\hline \multirow{3}{*}{ Variables* } & \multicolumn{4}{|c|}{ Days after processing / treatments } \\
\hline & \multicolumn{2}{|c|}{1} & \multicolumn{2}{|c|}{4} \\
\hline & Control & Treated & Control & Treated \\
\hline Soluble solids ${ }^{\mathrm{NS}}\left({ }^{\circ}\right.$ Brix $)$ & $8.93 \pm 0.94$ & $8.70 \pm 0.78$ & $8.22 \pm 0.33$ & $8.36 \pm 0.55$ \\
\hline Titratable acidity $^{\mathrm{NS}}$ (\% of citric acid) & $0.68 \pm 0.07$ & $0.75 \pm 0.11$ & $0.73 \pm 0.03$ & $0.71 \pm 0.10$ \\
\hline Ratio $^{\text {NS }}$ & $13.29 \pm 1.38$ & $11.80 \pm 1.93$ & $11.36 \pm 0.77$ & $11.93 \pm 1.19$ \\
\hline Ascorbic $\operatorname{acid}^{\mathrm{NS}}\left[\mathrm{mg}\left(100 \mathrm{~g}_{\text {pulp }}\right)^{-1}\right]$ & $30.68 \pm 4.05$ & $32.42 \pm 4.99$ & $32.17 \pm 2.60$ & $32.34 \pm 3.43$ \\
\hline
\end{tabular}


the minimal number of correct answers to characterize a difference between samples at 5\% significance is 18 , considering 36 judges (Table 1), as it was the case in this experiment. Therefore, there was no influence $(\alpha=5 \%)$ of the hydrothermal treatment on orange flavor.

On the $1^{\text {st }}$ day of analysis, that is, one day after processing, out of ten judges who had given correct answers, two said that hydrothermally-treated oranges presented better flavor than control ones, two found them to be waterier than control ones, two found them to be more acid than control, one found them to be overripe, one found them to be bitterer than control ones and two said that control oranges tasted overripe. Four days after processing, eight judges said that hydrothermally-treated oranges presented better flavor, one found them to be more acid than control ones, one found them to taste overripe, one said they presented a worse flavor than control ones and one made no comments.

Considering both days of analyses, results were not significant and the justifications of the judges were rather diverse, which implies that differences were due to the vegetable material or to judge percep- tion, rather than to the hydrothermal treatment carried out. Hydrothermally treated fruit scored significantly better on the appearance attribute (Table 3). Moreover, hydrothermally-treated oranges were preferred when compared to control ones at the $0.1 \%$ significance level. According to Meilgard (1991) test, a minimum of 36 answers (total of 48 tasters) in favor of a certain sample is necessary to characterize a significant difference between samples at $0.1 \%$ level (Table 1). The number of tasters who preferred the hydrothermally-treated sample was 43 . The reason for such preference was that the lower albedo residue promoted better appearance to oranges due to the intense orange color of segments, making the product more attractive. The peeled control oranges had their color masked by the albedo residue. Figure 2 illustrates the external appearance of oranges.

\section{Respiratory activity}

Hydrothermally-treated oranges had greater respiratory activity than control ones only during the first hour after processing, which indicates low and short-lasting stress due to heating (Figure 3).

Table 3 - Scores for external appearance of control and hydrothermally treated peeled 'Pera' sweet orange after two days of storage at $6^{\circ} \mathrm{C}$.

\begin{tabular}{lcccccc}
\hline \multirow{2}{*}{ Treatment } & \multirow{2}{*}{ Mean } & \multicolumn{5}{c}{ External appearance (score) } \\
\cline { 3 - 7 } & & Very good (5) & Good (4) & Regular (3) & Bad (2) & Very bad (1) \\
\hline Control & $3.3 \mathrm{~b}$ & 2 & 14 & 30 & 3 & - \\
Treated & $4.3 \mathrm{a}$ & 16 & 29 & 3 & - \\
\hline
\end{tabular}

Means followed by different letters are different $(P<0.05)$.

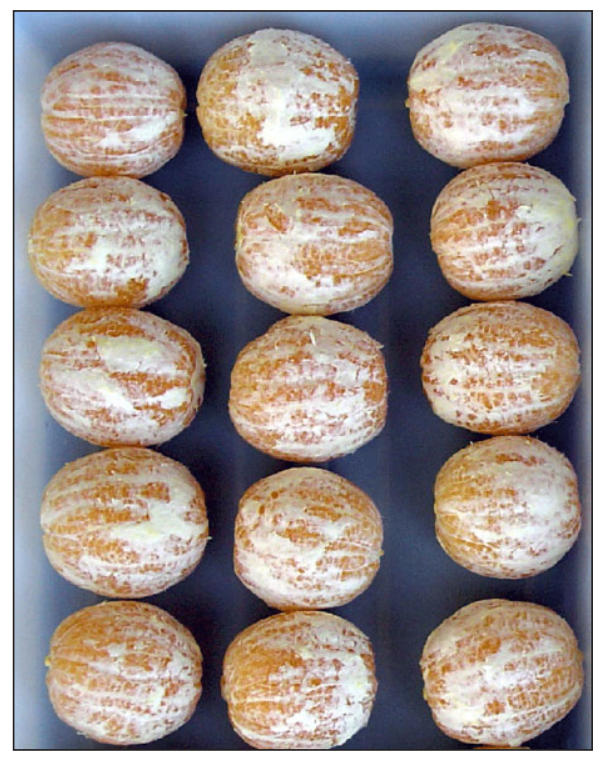

Control

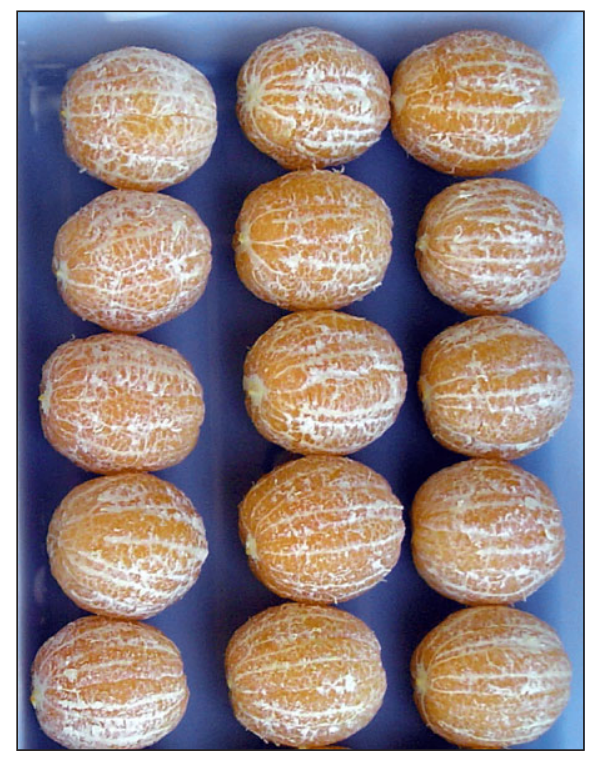

Treated

Figure 2 - External appearance of control and hydrothermally-treated 'Pera' sweet oranges.

Sci. Agric. (Piracicaba, Braz.), v.65, n.2, p.151-156, March/April 2008 


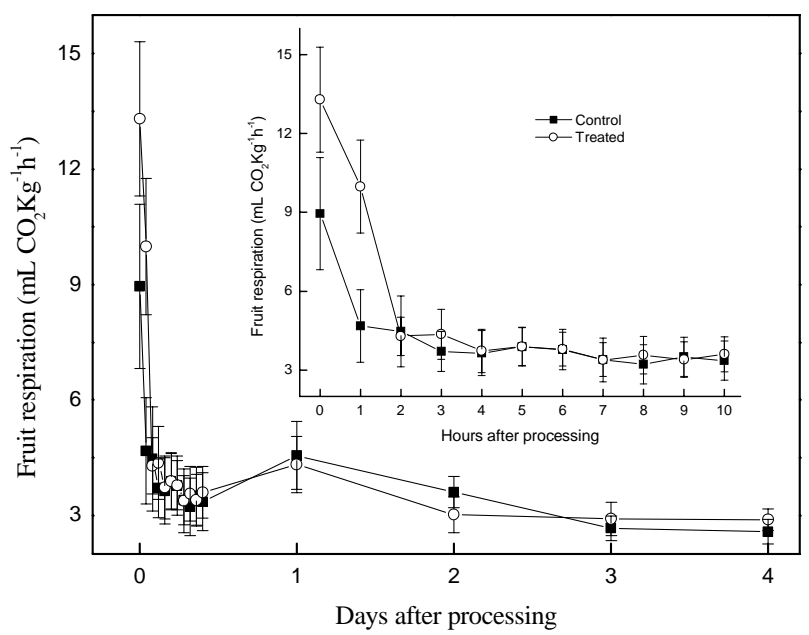

Figure 3 - Respiratory activity of control and hydrothermally treated 'Pera' sweet orange. Each point is the mean value of six replications (one fruit each) \pm SD.

Ketsa et al. (1999) observed greater respiratory activity in hydrothermally-treated mangos, while Serrano et al. (2004) verified that plums undergoing mechanical injuries after the hydrothermal treatment $\left(45^{\circ} \mathrm{C} / 10 \mathrm{~min}\right.$.) had lower respiratory activity when compared to non-treated fruits. Such results found in the literature imply that the effect of hydrothermal treatment on the respiratory activity depends on the considered product.

Considering the treatment period of $8 \mathrm{~min}$., unripeness and/or excessively thick skin can make peeling difficult in oranges. Therefore, other studies are necessary in order to determine the time-temperature combination that would make peeling easier without altering fruit quality, as well as to evaluate the heat propagation process inside the fruits for each species and variety, with their possible variations in constitutive characteristics.

\section{CONCLUSIONS}

Hydrothermal treatment technique can be used as a peeling process for 'Pera' oranges aimed at minimal processing, making the peeling of oranges easier and not affecting their respiratory rate and their physicochemical and sensorial qualities.

\section{REFERENCES}

BRUEMMER, J.H. Method of preparing citrus fruit sections with fresh fruit favor and appearance. US Patent 4,284,651. 1981.

CARVALHO, C.R.L.; MANTOVANI, D.M.B.; CARVALHO, P.R.N.; MORAES, R.M.M. Análise química de alimentos. Campinas: ITAL, $1990.121 \mathrm{p}$.

DAVIES, F.S.; ALBRIGO, L.G. Citrus. Wallingford: CABI, 1994. $254 \mathrm{p}$.

DEL CARO, A.; PIGA, A.; VACCA, V.; AGABBIO, M. Changes of flavonoids, vitamin $\mathrm{C}$ and antioxidant capacity in minimally processed citrus segments and juices during storage. Food Chemistry, v.84, p.99-105, 2004.

DONADON, J.R. Conservação de frutas cítricas minimamente processadas: tipos de descasque e temperaturas de armazenamento. Jaboticabal: UNESP/FCAV, 2005. 76p. Dissertação (Mestrado).

FERREIRA, V.L.P.; ALMEIDA, T.C.A; PETTINELLI, M.L.C.V. Análise sensorial: testes discriminativos e afetivos. Campinas: SBCTA, 2000. 127p.

FNP CONSULTORIA \& COMÉRCIO. Agrianual 2006: Anuário da Agricultura Brasileira. São Paulo: FNP, 2006. p.257-270.

HORTIBRASIL. Laranja. Available at: http://www.hortibrasil.org.br/ classificacao/ laranja/arquivos/normas.html. Accessed 03 Jan. 2006.

KETSA, S.; CHITRAGOOL, S.; KLEIN, J.D.; LURIE, S. Ethylene synthesis in mango fruit following heat treatment. Postharvest Biology and Technology, v.15, p. 65-72, 1999.

MEILGAARD, M.; CIVIlle, G.V.; CARR, B.T. Sensory evaluation techniques. Boca Raton: CRC Press, 1991. 354p.

O'MAHONY, M. Sensory evaluation of food: statistical methods and procedures. New York: Marcel Dekker, 1986. 487p.

PAO, S.; PETRACEK, P.D.; BROWN, G.E. Effect of infusion method on peel removal and storage quality of citrus. HortTechnology, v.6, p.409-413,1996.

PAO, S.; HAVEN, H.; PETRACECK, P.D. Citrus fruit peeling method. U.S.Patent 5,817,360. 1998.

SERRANO, M.; MARTÍNEZ-ROMERO, D.; CASTILLO, S.; GUILLE'N, F.; VALERO, D. Role of calcium and heat treatments in alleviating physiological changes induced by mechanical damage in plum. Postharvest Biology and Technology, v.34, p.155-167, 2004.

SHELLIE, K.C.; MANGAN, R.L. Postharvest disinfestation heat treatments: response of fruit and fruit fly larvae to different heating media. Postharvest Biology and Technology, v.21, p.51-60, 2000

WALL, M.M. Ripening behavior and quality of 'Brazilian' bananas following hot water immersion to disinfest surface insects. HortScience, v.39, p.1349-1353, 2004.

Received December 18, 2006 Accepted September 18, 2007 